\title{
Etnolech Determination of Toraja Community Kinship in a Foreign Land
}

\author{
Rita Tanduk $^{1 *}$ Elisabeth Mangera ${ }^{2}$, Sallolo Suluh ${ }^{3}$

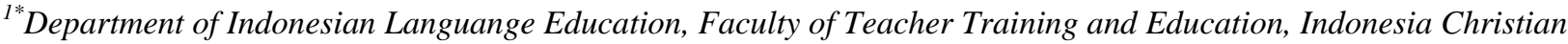 \\ University Toraja, Tana Toraja, Indonesia \\ ${ }^{2}$ Department of English Languange Education, Faculty of Teacher Training and Education, Indonesia Christian \\ University Toraja, \\ ${ }^{3}$ Department of Mechanical Engineering, Faculty of Engineering, Indonesia Christian University Toraja, Tana \\ Toraja, Indonesia \\ *Corresponing Author. Email: tandukrita@gmail.com
}

\begin{abstract}
This paper aims to describe the form of ethnolect speech of the Toraja people as a determining factor in kinship relations in overseas lands. This study uses a descriptive type of research. The methods used in data collection are free listening, recording, and note-taking methods. The data analysis method in this study begins with describing the data in the form of field notes, identifying the data, and then doing data reduction. The validity of the data obtained from the triangulation process with triangulation techniques from data sources, observations, and determination of theory. The results of this study indicate that there are several forms of ethnolect used by the Toraja people as a determining factor for kinship and intimacy in the overseas lands, including, as indicated by the background of (1) speech partners: having the same socio-cultural background; (2) speech intent and purpose: the same topic of conversation; (3) linguistic domain/environment: supportive social interaction context.
\end{abstract}

Keywords: ethnolect, Toraja people, sociolinguistics

\section{INTRODUCTION}

Humans use language as a means of communication as well as group identity. Therefore, there are many varieties of languages in the world that have unique characteristics that make them different from one another. This country can be seen, Indonesia is a country with thousands of differences in terms of skin color, customs, religion, traditional clothing to ethnicity, and language. According to Kridalaksana [1], language is a sound sign system that is agreed to be used by members of certain community groups in collaborating, communicating, and identifying themselves.

Language symbolizes the identity of a nation. People can identify a group of people through the language used. It is a unique language that makes it different from other languages in the world. The uniqueness of language can be found in every region, time, and individual. Even though someone is fluent in Indonesian (standard language), they are often encountered in daily interactions, often slipping regional dialects. Therefore, linguistic problems cannot be separated from the life of the speaker community. According to Fishman [2], language has a function. The functions of language include (1) Social functions, namely to form direction; (2) interpersonal function, namely to maintain good relations; (3) Imaginative function, which is to explain the realm of fantasy, and (4) Emotional function, which is to express moods such as: angry, sad, happy, and other forms of expression. Chaer [3] states that the function of language is a sociolinguistic problem in terms of speakers, listeners, topics, codes, and speech messages. This can be referred to as a unity contained in the formation of language variations.

\subsection{Dialect Variations}

Language variation is related to level, class, status, and social class. Dialect language variations are language variations from a group of speakers who are relatively in number, who are in a certain place, region, or area. Dialects from Greek, dialects, or accents are varieties of language that surround a group of speakers. Dialect contrasts with language variety, which is a form of language that is distinguished according to the context of use. These 
variations have differences from each other, but still, show many linguistic similarities so that they are not worthy of being called different languages. However, the distinction between the concept of dialect and its language is often motivated by symbolic and sociopolitical factors, not linguistics.

According to Wardhaugh, dialect can also be used to distinguish speech from the point of view of social class and groups that differ from other groups or some regional characteristics and from which region the speaker comes. Dialects are smaller in scope than languages because they are language variations. Dialect is part of a particular language.

In social interaction, there will certainly be differences in the speech that we usually say as an accent or dialect in language. According to Weijnen, et al quoted by the Center for Language Development and Development (1983) dialect is a linguistic system used by one community to distinguish it from other co

\subsection{Etnolect}

Etymologically, the word ethnolect consists of the words ethnic and dialect. Ethnicity is related to social groups or social or cultural systems that have a certain meaning or position; Dialect is a variety of language that varies according to the user (for example, a certain area or social group). Ethnolect is generally defined as a language variation that marks speakers as members of an ethnic group that originally used another language or a different variety.

According to another definition, ethnolect is any variety of speech (language, dialect, subdialect) associated with a particular ethnic group. It may be a distinguishing mark of social identity, both within the group and to outsiders. The term combines the concepts of ethnic group and dialect.

The way a person speaks can vary greatly within any ethnic group on a range of styles that can be mixed in different variants. Some may use it or have no features in ethnolect, while others may use it a lot. Therefore, it is difficult to draw a line between speakers and non-speakers of an ethnolect. Even though the qualifiers and modifiers are set in the definition to increase the fluidity of the concept, it still cannot solve the problem completely because the variations exist in complex and intricate patterns that are impossible to fully account for in a brief definition.

Ethnolect speakers tend to notice differences in their speech compared to others to some extent. They may therefore resent the use of prominent features in ethnolect when speaking to interlocutors who are not part of their ethnic group and may also be able to switch codes fluently between ethnolectal varieties or standard languages. Speakers who do so are considered "bidialectal". However, the selective and ethanolic use of elements is unpredictable, which then confounds the idea of code-switching.mmunities.

\section{METHOD}

This study uses a qualitative research type, which is the method used in producing descriptive research data. The research data is in the form of typical
Toraja greetings. The methods used in data collection are free listening, recording, and note-taking methods. This method is used to observe social activities, linguistic interactions, and physical aspects of social situations. The data analysis method in this study begins with describing the data in the form of field notes, identifying the data, and then doing data reduction. The validity of the data is obtained from the triangulation process with triangulation techniques of data sources, observations, and linkages, and theory determination.

\section{ANALYSIS}

Typical regional greetings are one of the ethnolect characteristics of the Toraja people. In particular, ethnolect by the Toraja people is usually used in certain situations as an introduction to the conversation before moving on to more serious topics. Ethnolek as a typical greeting of the Toraja people is often used to familiarize themselves so that the conversation can run smoothly.

The following are some typical Toraja greetings as a form of ethnolect commonly used in a particular region or location, including:

1. Umba susi kareba (how are you?)

Literally, ethanolec with the greeting umba susi kareba? means "how are you?". This utterance as a person's greeting to another person intended to open the conversation is also just small talk to express an attitude of friendliness towards others. The sentence is spoken with the intention of establishing good kinship or intimacy with other people. This greeting is usually done in a direct and indirect context.

2. Manasu moraka (Is it cooked?)

The greeting with the sentence manasu mo raka? means "is the food (rice) cooked". This sentence is usually uttered by neighbors or relatives who are just passing by to say hello or when they want to visit the house. This greeting does not at all mean to ask anything about cooking, although the question sentence will be answered by the host Iyo, manasumo which means 'yes, it's ripe' or taekpa, mamata pa which means 'not ripe'. In certain conditions, the questioner sometimes actually enters the house and takes a few grains of rice when it is cooked and eaten as a sign of intimacy between neighbors and residents in certain areas. From this greeting, it is also implied that Toraja people really appreciate food, especially rice. This is due to the philosophical thinking of the Toraja tribe which emphasizes that food (rice) plays an important role in making humans grow up.

3. Bongi melo (Good night)

The greeting of bongi melo "'good night" is a greeting or greeting at the end of a conversation or meeting at night. It also implies the meaning of 'beautiful night' experienced by the interlocutor. This is usually said with the aim of ending a 
beautiful conversation with the hope that some peace and peace be experienced together. For example, someone ends a conversation over the phone by saying bongi melo, etc.

4. Ta'kumande (Let's Eat)

Literally, ta kumande means "let's eat". This greeting is usually spoken when the host is eating and someone is passing by. In addition, this sentence is also said when someone wants to eat and invites others to eat together, even though it is known that the person invited to eat is still full. Sometimes the speaker will "force" the few people who are invited to taste the food available with the advice that they should not refuse the sustenance (food) offered.

5. Ta lendu' opa (Let's stop first)

As a greeting, the sentence ta lendu' opa means "let's stop first". This sentence is just a small talk from the host to everyone who passes in front of his house as a sign of hospitality. However, sometimes the host means serious and will host well if the person stops for a while. Sometimes the host provides coffee or hot tea to the guest or just accompanies to talk about how everyday life is being lived.

6. Kurre sumanga (Thank you)

Kurre sumanga means "thank you". In the context of Toraja society, saying kurre sumanga is a sign of gratitude for something that someone has obtained or desired. Usually, someone chants this greeting to repay love or retribution for others for the goodness that has been obtained. The goodness of others is not only seen in material terms but also morally. This speech is often referred to by the Toraja people as a response to establishing kinship with other people.

7. Tabe' (paying respect or apologizing)

The word tabe means an expression of 'respect or apology'. This speech can be said almost every day heard when interacting with other people. In the context of Toraja society, a person's politeness can be seen from his respect or politeness. The word tabe is usually spoken when someone asks for permission to be given a chance. Another intention is to express a request to be given a chance, for example, given the opportunity to walk ahead of the person in front of him, or accidentally make a mistake, etc. This indirectly shows an attitude of respect for others as well as establishing kinship with others.

\section{CONCLUSION}

In practice, someone who speaks will adapt himself to his environment. Different people have different dialects, accents, or accents, even if they are unconsciously embedded in everyone and appear when saying words in the regional or national language. Toraja people have a special dialect to characterize their identity with others. Ethnolek is a typical speech of the Toraja people which is often used to establish kinship with other people. The ethnolect form of the Toraja people is indicated by their greetings as a characteristic of their dialect. Typical greetings or greetings by the Toraja people as a determining factor for kinship and intimacy in a particular location or region. The determinants of the formation of kinship between Toraja people in the overseas land can be shown by the background of (1) speech partners: having the same socio-cultural background; (2) speech intent and purpose: the same topic of conversation; (3) linguistic domain/environment: supportive social interaction context.

\section{AUTHORS' CONTRIBUTIONS}

In the implementation and preparation of this research, of course, researchers divide their respective tasks in completing all the required data. The first researcher has full responsibility for this research, from planning to preparing the report. The main researcher plays a role in determining the research topic to theory and analysis. While the second and third researchers helped the first researcher collect data in the field by observing and classifying the data. After all the data was completed, then all researchers discussed together with the direction of analysis and preparation of research reports.

\section{ACKNOWLEDGMENTS}

With the completion of this research, the researcher would like to thank all parties, especially the respondents and informants, who have contributed to providing the required data. Hopefully, this research is useful for the development of the field of linguistics, especially in the field of sociolinguistics.

\section{REFERENCES}

[1] Kridalaksana, Harimurti. (2005). Bahasa dan Linguistik dalam Pesona Bahasa Langkah Awal memahami Linguistik (Language and Linguistics in the Enchantment of Language The first step to understanding Linguistics). Jakarta: PT. Main Library Gramedia

[2] Fishman. (1972). Language in Sociocultural Change. Stanford: University Press.

[3] Chaer, Abdul. (2005). Sosiolinguistik Suatu Pengantar (Sociolinguistics An Introduction). Jakarta: Rineka Cipta 